\title{
A new autosomal recessive retinitis pigmentosa locus maps on chromosome 2q31-q33
}

Mònica Bayés, Begoña Goldaracena, Amalia Martínez-Mir, María Ignacia Iragui-Madoz, Teresa Solans, Pilar Chivelet, Elena Bussaglia, María Antonia Ramos-Arroyo, Montserrat Baiget, Lluïsa Vilageliu, Susana Balcells, Roser Gonzàlez-Duarte, Daniel Grinberg

\begin{abstract}
Autosomal recessive retinitis pigmentosa (ARRP) is a genetically heterogeneous disease. To date, mutations in four members of the phototransduction cascade have been implicated in ARRP. Additionally, linkage of the disease to three loci on $1 p, 1 q$, and $6 p$ has been described. However, the majority of cases are still uncharacterised. We have performed linkage analysis in a large nuclear ARRP family with five affected sibs. After exclusion of several regions of the genome known to contain loci for retinal dystrophies, a genomic search for linkage to ARRP was undertaken. Positive lod scores were obtained with markers on 2q31-q33 (Zmax at $\theta=0.00$ of $4.03,4.12$, and 4.12 at D2S364, D2S118, and D2S389, respectively) defining an interval of about $7 \mathrm{cM}$ for this new ARRP locus, between D2S148 and D2S161. Forty-four out of 47 additional ARRP families, tested with markers on 2q32, failed to show linkage, providing evidence of further genetic heterogeneity.

(F Med Genet 1998;35:141-145)
\end{abstract}

Keywords: autosomal recessive retinitis pigmentosa; linkage analysis; chromosome $2 \mathrm{q}$

Genètica, Facultat de

Biologia, Universitat

de Barcelona,

Diagonal 645, 08071

Barcelona, Spain

M Bayés

A Martínez-Mir

Ll Vilageliu

S Balcells

R Gonzàlez-Duarte

D Grinberg

Hospital Virgen del

Camino, Irunlarrea 4,

Pamplona 31008, Spain

B Goldaracena

M I Iragui-Madoz

M A Ramos-Arroyo

Hospital de Sant Pau,

Pare Claret 167,

Barcelona 08025, Spain

T Solans

P Chivelet

E Bussaglia

M Baiget

Correspondence to:

Dr Gonzàlez-Duarte.

Received 20 February 1997 Revised version accepted for publication 4 August 1997

Retinitis pigmentosa (RP) is a group of inherited eye disorders characterised by night blindness, constriction of visual fields, photoreceptor degeneration, retinal pigment deposition, and diminished electroretinographic response. It is one of the more common causes of genetic blindness, with a prevalence of $1 / 3000-7000 .^{1} \mathrm{RP}$ is both clinically and genetically heterogeneous, comprising $\mathrm{X}$ linked, autosomal dominant, and autosomal recessive forms. Even within each type of RP there is further non-allelic heterogeneity. ${ }^{2}$

Autosomal recessive retinitis pigmentosa can be caused by mutations in the rhodopsin (RHO) ${ }^{3}$ the $\alpha,{ }^{4}$ or $\beta^{5-7}$ subunits of the cGMP phosphodiesterase (PDEA and PDEB, respectively), or the ' $\alpha$ subunit of the cGMP gated channel $(\mathrm{CNCG})^{8}$ genes. So far, mutations in the PDEB gene have been shown to explain $5-10 \%$ of cases, and therefore it constitutes the most prevalent locus characterised. ${ }^{7}$ Genetic linkage between ARRP and markers on $1 \mathrm{q}^{9}$ and $6 \mathrm{p}^{11}$ has been reported in large kindreds from The Netherlands, Pakistan, and the
Dominican Republic. Very recently, we have mapped a new ARRP locus on $1 p$ in a Spanish family. ${ }^{12}$ But to date, despite extensive studies, the molecular defect responsible for ARRP remains unidentified in most of the cases.

Here we describe a linkage study based on a large Spanish ARRP pedigree (named P-2) in which PDEB involvement had been previously ruled out. ${ }^{6}$ In this work we excluded the remaining genes and loci known to be involved in autosomal RP and in several other retinal dystrophies. Subsequently, a systematic search of the genome led us to identify a new ARRP locus on $2 \mathrm{q}$.

\section{Materials and methods \\ FAMILIES}

Family P-2 comes from the south of Spain. Parents I. 1 and I.2 are third cousins. The additional 47 small ARRP families have been described elsewhere. ${ }^{13} 14$

\section{CLINICAL EVALUATION}

All members of family P-2 were examined by ophthalmologists either in the Hospital Virgen del Camino in Pamplona or in the Hospital de la Santa Creu i Sant Pau, Barcelona. The clinical diagnosis was based on complete ophthalmological examination, including measurements of visual acuity, ophthalmoscopy, dark adaptation, perimetry, and ERG ampli- tudes.

\section{ANALYSIS OF DNA POLYMORPHISMS}

Genomic DNA was prepared from peripheral blood lymphocytes as described previously. ${ }^{15}$ Markers at the PDEB $^{16}$ and $\mathrm{RHO}^{17}$ loci, as well as all the anonymous markers used in this study, were from the Map Pairs set (Research Genetics, AL) and were analysed according to the manufacturer's instructions. Primers and conditions for examining the polymorphisms at the remaining genes have been described elsewhere: peripherin/RDS, ${ }^{18}$ ROM $1,{ }^{19} \mathrm{RCV} 1,{ }^{14}$ NRL (A Swaroop, personal communication), and PDEG ${ }^{20}$ The polymorphism in exon 16 of the $\mathrm{S}$-antigen gen $\mathrm{e}^{21}$ was detected by hybridisation with allele specific oligonucleotides (ASOH). ${ }^{22}$

\section{LINKAGE ANALYSES}

The reference genetic map used for this study was that reported by Gyapay et al. ${ }^{23}$ The allele frequencies were obtained from the Genome Data Base (GDB). Two point linkage analysis 
Table 1 Results of clinical examination of family P-2 members

\begin{tabular}{|c|c|c|c|c|c|c|c|c|c|}
\hline $\begin{array}{l}\text { Family } \\
\text { members }\end{array}$ & $\operatorname{Age}(y)$ & $\begin{array}{l}\text { Age of onset } \\
(y)\end{array}$ & Sex & Visual acuity & Fundus & Visual field & $E R G R$ & $E R G C$ & ERGRC \\
\hline I.1 & 73 & - & $M$ & $\begin{array}{l}\text { OD-1 } \\
\text { OS-1 }\end{array}$ & Nor & Nor & $\begin{array}{l}\text { OD-200 } \\
\text { OS-180 }\end{array}$ & $\begin{array}{l}\text { OD-80 } \\
\text { OS-56 }\end{array}$ & $\begin{array}{l}\text { OD-340 } \\
\text { OS-332 }\end{array}$ \\
\hline 1.2 & 63 & - & $\mathrm{F}$ & $\begin{array}{l}\text { OD-1 } \\
\text { OS-1 }\end{array}$ & Nor & Nor & $\begin{array}{l}\text { OD-270 } \\
\text { OS-444 }\end{array}$ & $\begin{array}{l}\text { OD-95 } \\
\text { OS-108 }\end{array}$ & $\begin{array}{l}\text { OD-438 } \\
\text { OS-520 }\end{array}$ \\
\hline II. 1 & 42 & 18 & $\mathbf{M}$ & $\begin{array}{l}\text { OD- } 0.2 \\
\text { OS-0.2 }\end{array}$ & RP-D & TV & $\begin{array}{l}\text { OD-0 } \\
\text { OS-0 }\end{array}$ & $\begin{array}{l}\text { OD-0 } \\
\text { OS-0 }\end{array}$ & $\begin{array}{l}\text { OD-0 } \\
\text { OS-0 }\end{array}$ \\
\hline II. 2 & 41 & - & $M$ & $\begin{array}{l}\text { OP-1 } \\
\text { OS-1 }\end{array}$ & Nor & Nor & $\begin{array}{l}\text { OD-390 } \\
\text { OS-450 }\end{array}$ & $\begin{array}{l}\text { OD-118 } \\
\text { OS-120 }\end{array}$ & $\begin{array}{l}\text { OD-450 } \\
\text { OS-510 }\end{array}$ \\
\hline II. 3 & 39 & - & $\mathbf{F}$ & $\begin{array}{l}\text { OD-1 } \\
\text { OS-1 }\end{array}$ & Nor & Nor & $\begin{array}{l}\text { OD- } \\
\text { OS- }\end{array}$ & $\begin{array}{l}\text { OD- } \\
\text { OS- }\end{array}$ & $\begin{array}{l}\text { OD- } \\
\text { OS- }\end{array}$ \\
\hline II. 4 & 38 & - & F & $\begin{array}{l}\text { OD-1 } \\
\text { OS-1 }\end{array}$ & Nor & Nor & $\begin{array}{l}\text { OD- } \\
\text { OS- }\end{array}$ & $\begin{array}{l}\text { OD- } \\
\text { OS- }\end{array}$ & $\begin{array}{l}\text { OD- } \\
\text { OS- }\end{array}$ \\
\hline II. 5 & 36 & 20 & F & $\begin{array}{l}\text { OD- } 0.05 \\
\text { OS-0.05 }\end{array}$ & RP-D & LSP-CS & $\begin{array}{l}\text { OD-0 } \\
\text { OS-0 }\end{array}$ & $\begin{array}{l}\text { OD-0 } \\
\text { OS-0 }\end{array}$ & $\begin{array}{l}\text { OD-0 } \\
\text { OS-0 }\end{array}$ \\
\hline II. 6 & 34 & - & F & $\begin{array}{l}\text { OD-1 } \\
\text { OS-1 }\end{array}$ & Nor & Nor & $\begin{array}{l}\text { OD-600 } \\
\text { OS-400 }\end{array}$ & $\begin{array}{l}\text { OD-170 } \\
\text { OS- } 180\end{array}$ & $\begin{array}{l}\text { OD-760 } \\
\text { OS-600 }\end{array}$ \\
\hline II. 7 & 33 & - & F & $\begin{array}{l}\text { OD-1 } \\
\text { OS-1 }\end{array}$ & Nor & Nor & $\begin{array}{l}\text { OD-420 } \\
\text { OS-400 }\end{array}$ & $\begin{array}{l}\text { OD-153 } \\
\text { OS-123 }\end{array}$ & $\begin{array}{l}\text { OD-504 } \\
\text { OS-540 }\end{array}$ \\
\hline II. 8 & 31 & - & F & $\begin{array}{l}\text { OD-1 } \\
\text { OS-1 }\end{array}$ & Nor & Nor & $\begin{array}{l}\text { OD- } \\
\text { OS- }\end{array}$ & $\begin{array}{l}\text { OD- } \\
\text { OS- }\end{array}$ & $\begin{array}{l}\text { OD- } \\
\text { OS- }\end{array}$ \\
\hline II. 10 & 28 & 20 & F & $\begin{array}{l}\text { OD-0.4 } \\
\text { OS-0.4 }\end{array}$ & RP-D & LSP & $\begin{array}{l}\text { OD-32 } \\
\text { OS-112 }\end{array}$ & $\begin{array}{l}\text { OD-30 } \\
\text { OS-80 }\end{array}$ & $\begin{array}{l}\text { OD-60 } \\
\text { OS-100 }\end{array}$ \\
\hline II. 11 & 27 & - & $\mathbf{M}$ & $\begin{array}{l}\text { OD-1 } \\
\text { OS-1 }\end{array}$ & Nor & Nor & $\begin{array}{l}\text { OD-510 } \\
\text { OS-540 }\end{array}$ & $\begin{array}{l}\text { OD-170 } \\
\text { OS-140 }\end{array}$ & $\begin{array}{l}\text { OD-690 } \\
\text { OS-730 }\end{array}$ \\
\hline II. 12 & 26 & - & M & $\begin{array}{l}\text { OD-1 } \\
\text { OS-1 }\end{array}$ & Nor & Nor & $\begin{array}{l}\text { OD-500 } \\
\text { OS-490 }\end{array}$ & $\begin{array}{l}\text { OD-196 } \\
\text { OS-168 }\end{array}$ & $\begin{array}{l}\text { OD-678 } \\
\text { OS-650 }\end{array}$ \\
\hline II. 14 & 24 & 20 & $M$ & $\begin{array}{l}\text { OD-0.9 } \\
\text { OS-0.9 }\end{array}$ & RP-D & LSP & $\begin{array}{l}\text { OD-240 } \\
\text { OS-208 }\end{array}$ & $\begin{array}{l}\text { OD-85 } \\
\text { OS-100 }\end{array}$ & $\begin{array}{l}\text { OD-270 } \\
\text { OS-224 }\end{array}$ \\
\hline II. 15 & 23 & 15 & $\mathbf{M}$ & $\begin{array}{l}\text { OD-0.1 } \\
\text { OS- } 0.1\end{array}$ & RP-D & LSP-CS & $\begin{array}{l}\text { OD-0 } \\
\text { OS-0 }\end{array}$ & $\begin{array}{l}\text { OD-0 } \\
\text { OS-0 }\end{array}$ & $\begin{array}{l}\text { OD-0 } \\
\text { OS-0 }\end{array}$ \\
\hline
\end{tabular}

Fundus (RP-D: diffuse loss of the RPE, Nor: normal); visual field (LSP: loss of retinal sensitivity in far periphery, CS: centra scotoma, TV: tunnel vision), ERGR, ERGC, and ERGRC (rod, cone, and rod-cone b wave amplitudes in the electroretinogram; lower limit normal b wave is 250,100 , and 350 microvolts, respectively).

was performed using the MLINK program from the LINKAGE package, version $5.1 .^{24}$ Complete penetrance and a disease allele frequency of 0.015 were assumed. ${ }^{11}$ As usually accepted, lod scores below -2 were assumed to be evidence for excluding linkage, whereas lod scores above 3 were considered to indicate linkage.

MUTATION SCREENING

Primer pairs to amplify the coding regions of the PDEG gene were designed from the published sequences. ${ }^{25}$ PCR and SSCP analy-

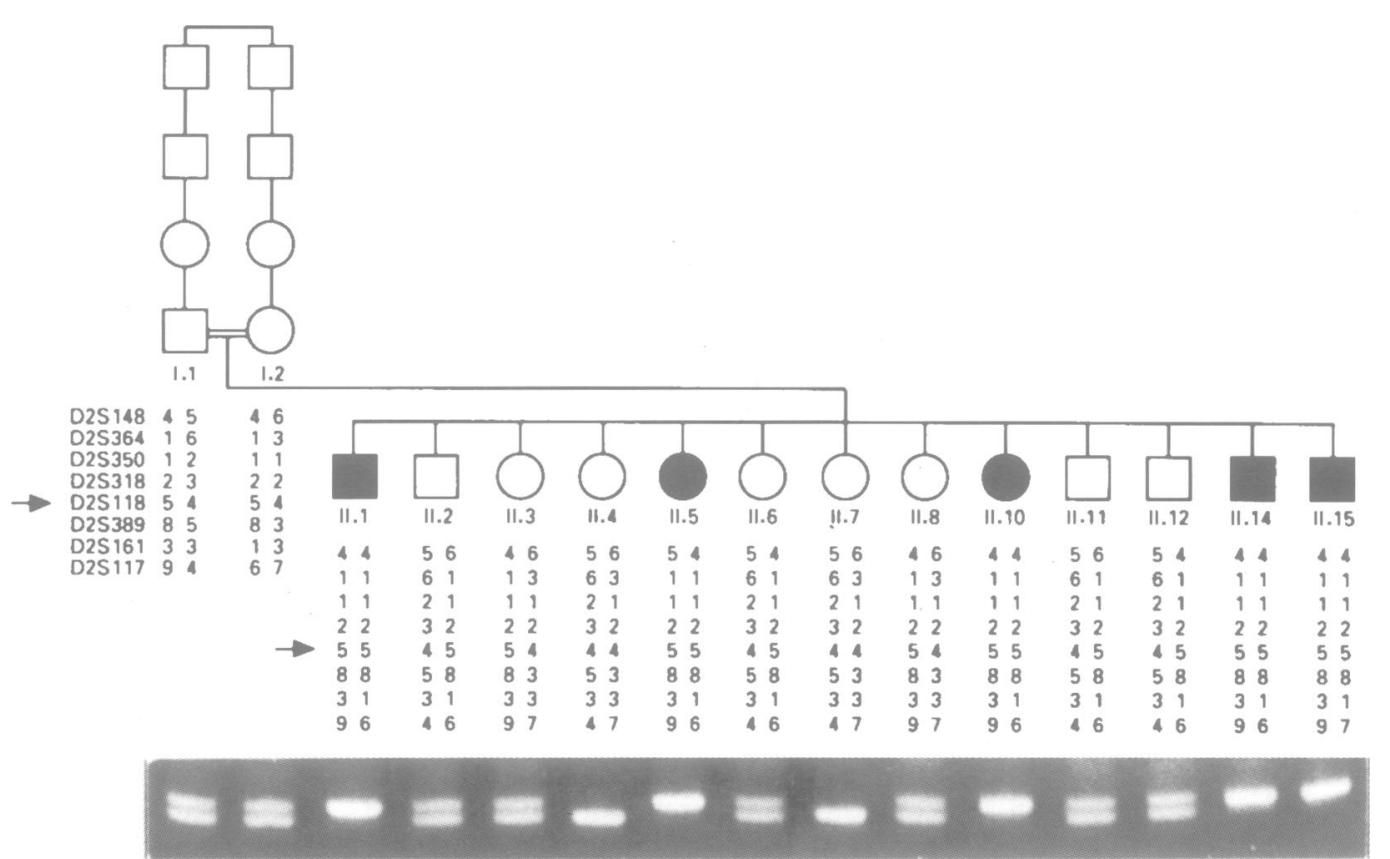

ses were performed as described previously, ${ }^{14}$ using a silver staining protocol. Each PCR fragment was analysed under three different SSCP conditions, varying glycerol (0 or $5 \%$ ) and acrylamide ( 8 or $12 \%$ ) concentrations and the running temperature (RT or $4^{\circ} \mathrm{C}$ ).

Analysis of the chimerin gene was performed using standard methods ${ }^{26}$ of restriction digestion of genomic DNA followed by Southern blotting onto Hybond- $\mathrm{N}^{+}$ membrane and hybridisation with a radiolabelled cDNA probe (kindly provided by $\mathrm{C}$ Hall). 

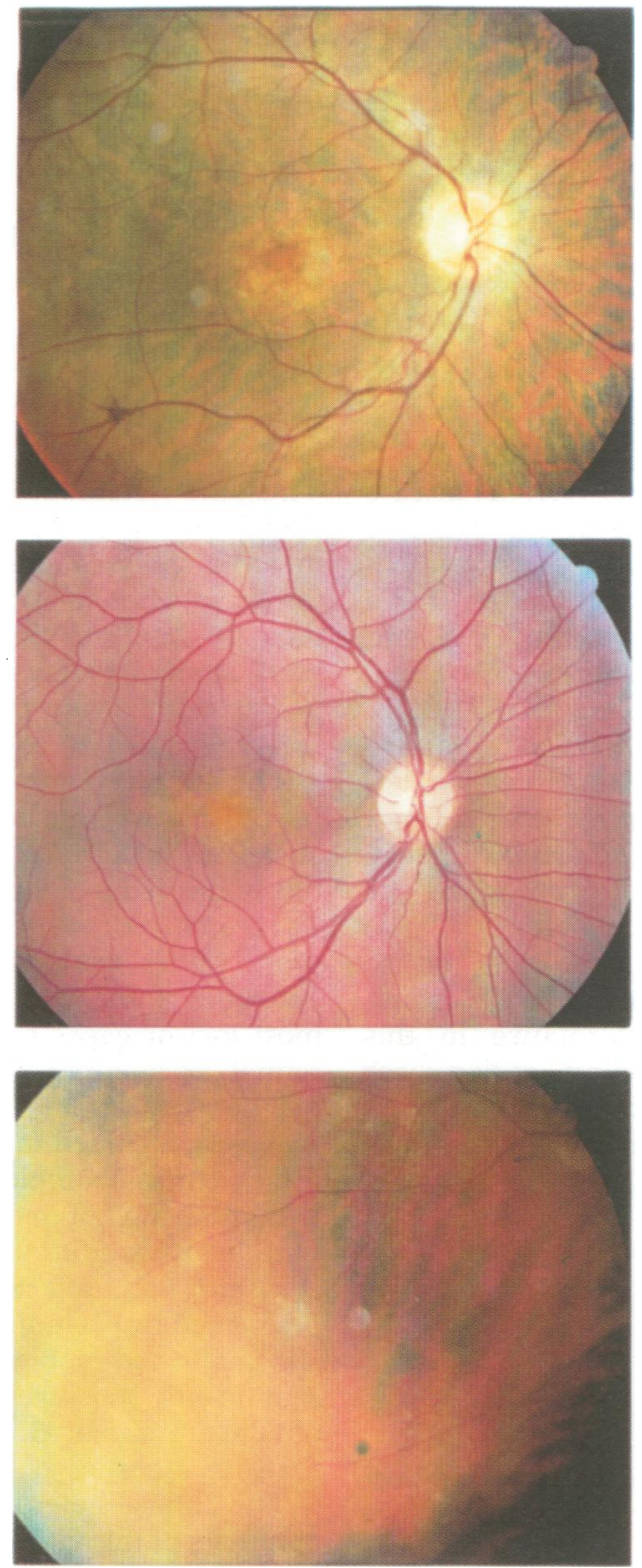

B
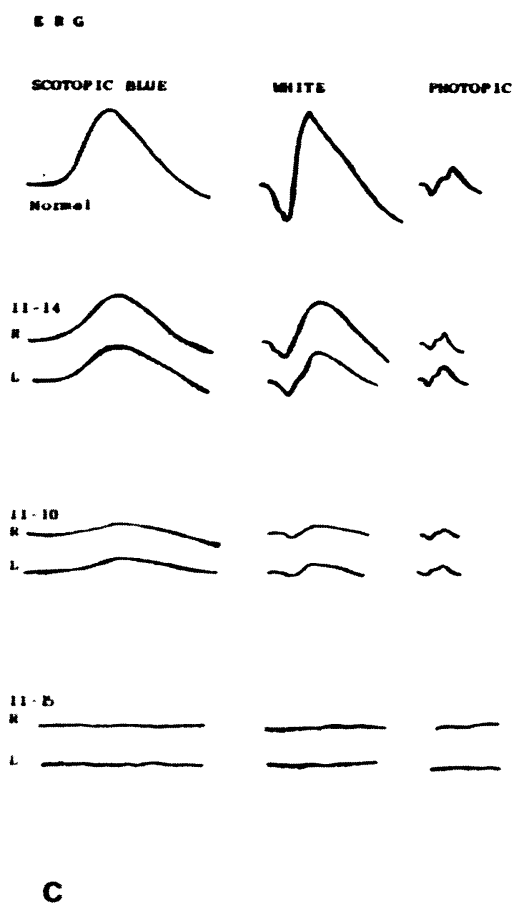

${ }_{40}^{100} L_{\text {son }}$

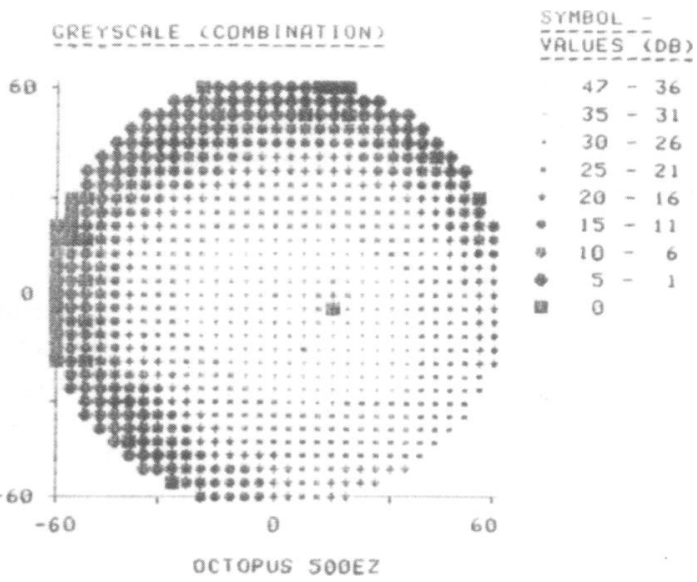

Figure 2 (A) Retinography of II.14 and II.15. In II.15 (top) pallor of the optic disc, arterial attenuation, and pigmentary alterations in the perifoval region are evident. A perivascular pigment deposit is also observed. Note the choriocapillaris atrophy allowing visualisation of the large choroidal vessels. In II.14 (middle and bottom), although vessel attenuation is not apparent, pallor of the optic disc and a similar macular alteration to that of II.15 are present (middle); $a$ pigmentary deposit in the inferior retina can also be observed (bottom). (B) ERG patterns of II.10, II.14, and II.15. Retinal degeneration in the family follows the expected progression as is well illustrated in these three patients. A primary scotopic hipovoltage is followed by cone involvement: II. 14 has photopic ERG response well conserved, II. 10 shows slightly decreased values, whereas II. 15 shows absent response. (C) Visual field of patient II.14, right eye, showing loss of retinal sensitivity in the far periphery.

Results

CLINICAL FINDINGS

We have studied a large consanguineous pedigree in which RP segregates in an autosomal recessive manner (fig 1 ). The clinical features of the five affected subjects satisfy the current diagnostic criteria for $R P,{ }^{27}$ in spite of a relevant intrafamilial variability (table 1 ). The disease leads to disturbances in both peripheral and central vision by the second decade of life. Characteristic fundus changes, namely disc pallor, retinal vascular attenuation, and intraretinal pigment deposits in the midperiphery were observed in all affected subjects although to different degrees (fig 2A). Characteristic macular alterations were also present. All patients except II.10 and II.14 showed extinguished rod and cone electroretinograms. However, these two subjects, aged 28 and 24 respectively, had rod ERG responses which were significantly reduced in amplitude (fig 2B). Cone response was also decreased in II.10 but still well preserved in II.14, thus confirming the primary alteration of rods. Visual acuity was decreased in all patients (ranging from 0.05 to 0.4 ), except in II.14. Scotopic perimetry of this patient (fig 2C) showed alterations for most of the visual field reaching a complete loss of retinal sensitivity in the far periphery in both eyes. A further clinical test of this patient included EOG examination which gave an Arden ratio of 2.2 (normal threshold 1.75), ruling out a primary RPE dystrophy. 
Table 2 Two point lod scores $(Z)$ between ARRP and markers on chromosome $2 q$ in family $P$-2. Maximum lod scores at corresponding recombination fractions are shown in bold type

\begin{tabular}{llllllllll}
\hline \multicolumn{1}{c}{ Recombination fraction $(\theta)$} \\
\cline { 2 - 10 } Marker & 0.00 & 0.01 & 0.05 & 0.1 & 0.2 & 0.3 & 0.4 & $Z \max$ & $\theta \max$ \\
\hline D2S148 & $-\infty$ & 1.53 & 1.95 & 1.91 & 1.51 & 0.95 & 0.34 & $\mathbf{1 . 9 6}$ & 0.06 \\
D2S364 & 4.03 & 3.93 & 3.55 & 3.07 & 2.15 & 1.26 & 0.43 & $\mathbf{4 . 0 2}$ & 0.00 \\
D2S350 & 2.19 & 2.14 & 1.93 & 1.68 & 1.19 & 0.72 & 0.27 & $\mathbf{2 . 1 9}$ & 0.00 \\
D2S318 & 1.99 & 1.95 & 1.76 & 1.54 & 1.10 & 0.68 & 0.25 & $\mathbf{1 . 9 9}$ & 0.00 \\
D2S118 & 4.12 & 4.02 & 3.63 & 3.14 & 2.19 & 1.28 & 0.44 & $\mathbf{4 . 1 2}$ & 0.00 \\
D2S389 & 4.12 & 4.02 & 3.63 & 3.15 & 2.20 & 1.29 & 0.44 & $\mathbf{4 . 1 2}$ & 0.00 \\
D2S161 & 0.31 & 0.41 & 0.60 & 0.66 & 0.58 & 0.38 & 0.13 & $\mathbf{0 . 6 6}$ & 0.11 \\
D2S117 & $-\infty$ & 0.77 & 1.45 & 1.56 & 1.28 & 0.79 & 0.27 & $\mathbf{1 . 5 6}$ & 0.09 \\
\hline
\end{tabular}

EXCLUSION OF CANDIDATE GENES AND LOCI

Initially, linkage was tested between the disease and loci previously reported as the cause of ARRP, ADRP, Usher syndrome, Bardet-Biedl syndrome, or other retinal dystrophies (for a comprehensive review see reference 28 and citations therein). Candidate genes for retina eye disorders, including PDEB, RHO, RDS, ROM1, RCV1, NRL, and PDEG, were also evaluated. No evidence of cosegregation between the disease and any of the markers analysed was detected and significantly negative lod scores were achieved, thus excluding the region known to contain each locus.

The polymorphism within the gene for the gamma subunit of the cGMP phosphodiesterase (PDEG) was not informative in this family. Therefore, its coding region was analysed by single strand conformation polymorphism (SSCP) and no aberrant pattern was detected (data not shown).

\section{SYSTEMATIC LINKAGE ANALYSIS}

Subsequently, screening for linkage was performed with markers randomly distributed throughout the genome. After testing over 75 anonymous microsatellites, linkage was observed with markers on chromosome 2q. D2S118, which has been localised by physical methods to $2 \mathrm{q} 32$, yielded a maximum lod score of 4.12 at $\theta=0.00$, when the consanguinity loop was taken into account. Other microsatellite markers in the region were analysed and two point lod score values are shown in table 2 . Haplotype construction using these markers provided direct evidence of recombination events that place the ARRP locus in the $11 \mathrm{cM}$ genetic interval defined by $\mathrm{D} 2 \mathrm{~S} 148$ and D2S117. Homozygosity mapping confirmed the linkage data and reduced the ARRP locus region to a $7 \mathrm{cM}$ genetic interval, between D2S148 and D2S161 (2q31-2q33) (fig 1).

CANDIDATE GENES ON 2q31-q33

We tested a three allele polymorphism within the gene encoding S-antigen (SAG), initially mapped to $2 \mathrm{q} 24-37,{ }^{29}$ and it failed to cosegregate with the disease in family P-2. Furthermore, a refinement of the genetic ${ }^{22}$ and physical $^{30}$ localisation of the gene showed its distal location in relation to the ARRP locus described here. The candidacy of the chimerin gene $^{31}$ (located at 2q31-q32.1) was also evaluated. Using the cDNA as a probe, Southern analysis failed to show any gene deletions or rearrangements in the affected subjects.
EVALUATION OF THE 2q32 LOCUS IN OTHER ARRP FAMILIES

In order to determine whether other ARRP families show positive lod scores for the $2 q 32$ region, segregation of D2S118 was tested in 47 small ARRP pedigrees. Slightly positive lod scores were obtained in three families, whereas involvement of the 2q32 ARRP locus was excluded, either by linkage or homozygosity analyses, in 44 pedigrees.

\section{Discussion}

Autosomal recessive retinitis pigmentosa has been shown to present a high degree of genetic heterogeneity, both allelic and non-allelic. Thus, the systematic linkage approach for new ARRP loci has the difficulty that pedigrees must be analysed separately and are generally not large enough to yield significant linkage data. To date, genetic linkage analysis has only been applied to four consanguineous ARRP pedigrees, allowing the identification of three loci on $1 \mathrm{p},{ }^{12} 1 \mathrm{q},{ }^{9}{ }^{10}$ and $6 \mathrm{p} .{ }^{11}$

The nuclear family $\mathrm{P}-2$ studied in this paper is sufficiently large to enable genetic linkage analysis. Linkage and homozygosity studies on this family led us to map a new ARRP locus to 2q31-q33. No other significantly positive lod score values were found with either of the anonymous markers analysed. Furthermore, most loci or genes reported to be involved in retinal degeneration were excluded as the cause of the disease in this family. Overall, our screening included more than 100 markers.

The clinical complexity of RP, together with the possibility of reduced penetrance, could blur linkage studies. For a more stringent linkage test, an affecteds only analysis was performed by excluding the phenotype data for all unaffected subjects. Even in this case, significantly positive lod score values were obtained $(\mathrm{Z} \max =3.12$ at $\theta=0.00$ at the D2S118 locus).

The clinical heterogeneity found in affected members of this family is remarkable, although it is not an uncommon feature of RP. The segregation of a protective allele at some other locus or the influence of as yet unidentified environmental factors or both could account for the variability found.

Cosegregation and homozygosity data in $\mathbf{4 7}$ Spanish ARRP families show that the locus on 2q fails to explain most of the ARRP cases. Using the same panel of families, we previously reported that loci on $1 \mathrm{q}$ and $6 \mathrm{p}$ are also minor ARRP loci. ${ }^{13}$ These results add further evidence of the high degree of genetic heterogeneity in ARRP. The authors thank the families for their generous cooperation.
In particular we are most grateful to J M Casado and his family In particular we are most grateful to $\mathrm{M}$ Casado and his family for their enthusiastic participation in the study. In addition, we thank I Martinez, D Valverde, and the "Serveis CientificoTècnics" of Universitat de Barcelona for outstanding technical support, $R$ Casaroli-Marano for helpful discussion of the ophthalmological data, and R Rycroft for revising the English This work was supported by Spanish CICYT (SAF93-0479062-01 and SAF96-0329) and the "Federación de Asociaciones de Afectados de Retinosis Pigmentaria del Estado Español" (FAARPE). A Martínez-Mir and M Bayés are recipients of fellowship from the Generalitat de Catalunya.

1 Heckenlively JR, Yoser SL, Friedman LH, Oversier JJ Clinical findings and common symptoms in retiniti pigmentosa. Am f Ophthalmol 1988;105:504-11. 
2 Dryja TP, Li T. Molecular genetics of retinitis pigmentosa. Hum Mol Genet 1995;4:1739-43.

3 Rosenfeld PJ, Cowley GS, McGee TL, Sandberg MA, Berson EL, Dryja TP. A null mutation in the rhodopsin gene causes rod photoreceptor dysfunction and autosomal recessive retinitis piomentosa. Nat Genet 1992;1:209-13.

4 Huang SH, Pittler SJ, Huang XH, Oliveira L, Berson EL, Dryja TP. Autosomal recessive retinitis pigmentosa caused Dryja TP. Autosomal recessive retinitis pigmentosa caused
by mutations in the $\alpha$-subunit of rod cGMPby mutations in the $\alpha$-subunit of rod

5 McLaughlin ME, Ehrhart TL, Berson EL, Dryja TP. Recessive mutations in the gene encoding the $\beta$-subunit of rod phosphodiesterase in patients with retinitis pigmentosa. Proc Natl Acad Sci USA 1995;92:3249-53.

6 Bayés M, Giordano M, Balcells S, et al. Homozygous tandem duplication within the gene encoding the betasubunit of rod phosphodiesterase as a cause for autosomal recessive retinitis pigmentosa. Hum Mutat 1995;5:228-34.

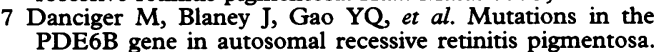
Genomics 1995;30:1-7.

8 Dryja TP, Finn JT, Peng YW, McGee TL, Berson EL, Yau KW. Mutations in the gene encoding the alpha subunit of the rod cGMP-gated channel in autosomal recessive retinithe rod cGMP-gated channel in autosomal recessive retini-

tis pigmentosa. Proc Natl Acad Sci USA 1995;92:1177-81.

van Soest $S$, Vandenborn LI, Gal A, et al. Assignment of a gene for autosomal recessive retinitis pigmentosa (RP12) to chromosome 1q31-q32.1 in an inbred and genetically heteroge 504 .

10 Leutelt J, Oehlmann R, Younus F, et al. Autosomal recessive retinitis pigmentosa locus maps on chromosome $1 \mathrm{q}$ in a large consanguineous family from Pakistan. Clin Genet 1995;47:122-4.

11 Knowles JA, Shugart Y, Banerjee $P$, et al. Identification of a locus, distinct from RDS-peripherin, for autosomal reces-
sive retinitis pigmentosa on chromosome $6 \mathrm{p}$. Hum Mol Genet 1994;3:1401-3.

12 Martínez-Mir A, Bayés M, Vilageliu Ll, et al. A new locus for autosomal recessive retinitis pigmentosa maps to 1 p13p21. Genomics 1997;40:142-6.

13 Bayés M, Martínez-Mir A, Valverde D, et al. Autosomal recessive retinitis pigmentosa in Spain: evaluation of 4 recessive retinitis pigmentosa in Spain: evaluation of 4 genes and 2

14 Bayés M, Valverde D, Balcells $S$, et al. Evidence against involvement of recoverin in autosomal recessive retinitis pigmentosa in 42 Spanish families. Hum Genet 1995;96:8994

15 Miller SA, Dyke DD, Polesky HF. A simple salting out procedure for extracting DNA from human nucleated cells. Nucleic Acids Res 1988;16:1215.

16 Weber B, Riess O, Daneshvar H, Graham R, Hayden R (CA)n-dinucleotide repeat at the PDEB locus in $4 \mathrm{p} 16.3$. Hum Mol Genet 1993;2:827.
17 Weber JL, May PE. Abundant class of human DNA polymorphisms which can be typed using the polymerase chain reaction. Am f Hum Genet 1989;44:388-96.

18 Kumar-Singh R, Jordan SA, Farrar GJ, Humphries P. Poly (T/A) polymorphism at the human retinal degeneration (T/A) polymorphism at the human retinal degen

19 Bascom RA, Liu L, Humphries P, Fishman GA, Murray JC, McInnes RR. Polymorphisms and rare sequence variants at the ROM1 locus. Hum Mol Genet 1993;2:1975-7.

20 Hahn LB, Berson EL, Dryja TP. Evaluation of the gene encoding the gamma subunit of rod phosphodiesterase in retinitis pigmentosa. Invest Ophthalmol Vis Sci 1994;35: 1077-82.

21 Sheffield VC, Beck JS, Nichols B, Cousineau A, Lidral AC, Stone EM. Detection of multiallele polymorphisms within gene sequences by GC-clamped denaturing gradient gel gene sequences by GC-clamped denaturing gradien
electrophoresis. Am $\mathcal{f}$ Hum Genet 1992;50:567-75.

22 Valverde D, Bayés M, Martínez I, et al. Genetic fine localization of the arrestin (S-antigen) gene $4 \mathrm{cM}$ distal from D2S172. Hum Genet 1994;94:193-4.

23 Gyapay G, Morissatte J, Vignal A, et al. The 1993-94 Généthon human genetic linkage map. Nat Genet 1994;7:246338.

24 Lathrop GM, Lalouel JM, Julier C, Ott J. Strategies for multilocus linkage analysis in humans. Proc Natl Acad Sci USA 1984;81:3443-6.

25 Piriev NI, Khramtsov NV, Lipkin VM. Cloning and characterization of the gene encoding the cGMPphosphodiesterase gamma-subunit of human rod photoreceptor cells. Gene 1994;151:297-301.

26 Sambrook J, Fritsch EF, Maniatis T. Molecular cloning: a laboratory manual. New York: Cold Spring Harbor Laboratory Press, 1989.

27 Marmor MF, Aguirre G, Arden GO, et al. Retinitis pigmentosa. A symposium on terminology and methods of examination. Ophthalmology 1983;90:126-31.

28 Rosenfeld PJ, McKusick VA, Amberger JS, Dryja TP. Recent advances in the gene map of inherited eye disorders. Primary hereditary diseases of the retina choroid, and vitreous. F Med Genet 1994;31:903-15.

29 Ngo JT, Klisak I, Sparkes RS, et al. Assignment of the S-antigen gene (SAG) to human chromosome 2q24-q37. Genomics 1990;7:84-7.

30 Calabrese G, Sallese M, Stornaiuolo A, Stuppia L, Palka G, Deblasi A. Chromosome mapping of the human arrestin (SAG), beta-arrestin 2 (ARRB2), and beta-adrenergic receptor kinase 2 (ADRBK2) genes. Genomics 1994;23. 286-8.

31 Hall C, Sin WC, Teo M, et al. a2-chimerin, an SH2containing GTPase-activating protein for the ras-related protein $\mathrm{p} 21^{\text {rac }}$ derived by alternate splicing of the human n-chimerin gene, is selectively expressed in brain regions and testes. Mol Cell Biol 1993;13:4986-98. 